\title{
OSMR wt Allele
}

National Cancer Institute

\section{Source}

National Cancer Institute. OSMR wt Allele. NCI Thesaurus. Code C51376.

Human OSMR wild-type allele is located in the vicinity of 5p13.1 and is approximately 88

$\mathrm{kb}$ in length. This allele, which encodes oncostatin-M specific receptor beta subunit protein, is involved in cellular proliferation. 